\title{
Development of marketing innovations in Uzbekistan
}

\author{
Radjabov Bunyod Abduhalilovich ${ }^{1}$ \\ ${ }^{1}$ Student of Tashkent State Economic University, Uzbekistan
}

\begin{abstract}
This article explores the scientific and methodological aspects of the interconnected development of technological, marketing and organizational innovation. It is based on the linkages between marketing innovation and technological innovation. The ways in which marketing innovation can be effectively utilized in enterprise operations in Uzbekistan.
\end{abstract}

Keywords: marketing, innovative marketing, innovative marketing technologies, competitiveness, infrastructure.

\section{Introduction}

Rapid introduction of modern innovative marketing technologies in economic, social and other sectors using effective marketing methods is an important condition for the dynamic development of the Republic of Uzbekistan.

President of the Republic of Uzbekistan September 9, 2018 "On approval of the Strategy of Innovative Development of the Republic of Uzbekistan in 2019 - 2021" The special resolution PF-5544 outlines "Achievement of the Republic of Uzbekistan to be among the 50 leading countries in the Global Innovation Index Ranking by 2030" and a number of other objectives for innovative development. Successful implementation of these tasks will require the solution of scientific, methodological and practical problems aimed at the development and implementation of innovative marketing strategies at our enterprises.

A number of scientific studies on the development and implementation of marketing innovations in the world practice have been conducted, and their methodological bases will help to establish the appropriate approaches to the development of innovative marketing strategies in domestic enterprises.

\section{Literature review}

The first scientific innovations in marketing innovations were introduced by Theodore Levitt in 1960 and justified their impact on the effectiveness of enterprise operations ${ }^{1}$.

Many large companies and their labs around the world create many innovative products, but they rarely introduce marketing innovations. Marketing innovations often occur in the unknown, unplanned and random, outside of the central core of networks because of coincidences.

Innovation is the main tool for ensuring competitive advantage of the enterprise and increasing its economic efficiency ${ }^{2}$. Innovation is characterized by product, process, organizational and marketing innovations ${ }^{3}$.

Most research focuses on product, process and organizational innovation ${ }^{4}$. Increasing competition in the global market suggests that marketing innovations are a process involving enterprise growth, competitiveness, and strategies ${ }^{5}$.

\footnotetext{
${ }^{1}$ Levitt, T. (1960) 'Growth and profits through planned marketing innovation', Journal of Marketing, Vol. April, pp. 1-8

${ }^{2}$ Gunday, G., Ulusoy, G., Kilic, K., \& Alpkan, L. (2011). Effects of innovation types on firm performance. International Journal of Production Economics, 133(2), 662-676.

${ }^{3}$ OECD. (2005). Oslo Manual. Proposed Guidelines for Collecting and Interpreting Innovation Data, 3rd Edition. Paris.

${ }^{4}$ Cleff, T., \& Rennings, K. (1999). Determinants of environmental product and process innovation. European Environment, 9(5), 191-201.; Danneels, E. (2002). The dynamics of product innovation and firm competences. Strategic Management Journal, 23(12), 1095-1121.; Subramanian, A., \& Nilakanta, S. (1996). Organizational innovativeness: exploring the relationship between organizational determinants of innovation, types of innovations, and measures of organizational performance. Omega, 24(6), 631-647.

${ }^{5}$ Aghion, P., Bloom, N., Blundell, R., Griffith, R., \& Howitt, P. (2002). Competition and innovation: An inverted U relationship: National Bureau of Economic Research.; Halpern, N. (2010). Marketing innovation: Sources, capabilities and consequences at airports in Europe's peripheral areas. Journal of Air Transport Management, 16(2), 52-58.; Nickell, S. J. (1996). Competition and corporate performance. Journal of Political Economy, 724-746.
} 
However, this does not mean that marketing innovations have just come into play, but in general terms we do not keep statistics on such concepts and that they are reflected in other regulations, such as the OLOJECTIVES AND SCOPE OF THE MANUAL. Accordingly, in 2005 OSLO was included as a separate section on marketing innovations and was reflected in statistical reports of countries around the world.

Also, strategic marketing theories have little focus on marketing innovation. Marketing capabilities of the enterprise are determined by the increase in sales of products and services ${ }^{6}$.

The emphasis is on data collection, dissemination, analysis and environmental conservation ${ }^{7}$. Innovative marketing marketing opportunities and enterprise competitiveness are interrelated concepts ${ }^{8}$. Marketing plays a key role in securing the competitive edge, and marketing within the competitive strategy plays the usual role.

Marketing opportunities are the key to not only innovative development but also success in the innovation market. As marketing innovations are officially incorporated into OSLO, collecting information on marketing innovation has enabled researchers to conduct research in various areas. Therefore, it is important to note that research in this area is insufficient in many countries of the world. It is worth noting that marketing innovation research has been conducted mainly in Europe and Asia. Scientists in our country, especially in the USA, have not done enough research and there is insufficient scientific research on the development and implementation of innovative marketing strategies.

While managing corporate innovation in production processes, as well as introducing new and new products, it also strives to create and keep track of the effectiveness of marketing by introducing innovative technologies "[3]. According to Livvit, marketing innovation is seen as a process that is ignored by businesses and occurs spontaneously or by accident.

Many current studies have found that beyond product innovation, that is, there are cases where economic efficiency cannot be achieved by simply linking it [4].

In general, it is important to develop systematic approaches to which marketing innovations should be widely studied. It can be seen that these conceptual approaches provide a comprehensive analysis of innovative marketing and its study as a separate area of marketing.

When studying the methodological aspects of the formation of marketing innovations it is necessary to find the answers of following questions:

what are marketing innovations and how they will change over the life cycle of the industry;

what impact does marketing innovation have on enhancing enterprise competitiveness and market leadership?

What synergistic effect is observed as a result of the introduction of marketing innovations?

These issues need to understand marketing innovations, determine the dynamics of its development, frequency of industry growth, compare product or production innovation with marketing innovations, and identify interrelated development and change.

In the following process, we examine the impact of marketing innovation on enterprise development and assess the impact of technological and organizational product innovation on marketing innovation. The introduction of marketing innovations in close contact with product innovations is an urgent issue, as the old methods of introducing new products into the market are ineffective. The use of old marketing techniques to enter the market with a new product does not ensure the sufficient volume of sales of the new product.

Application of marketing innovations can increase value added, reduce costs and increase consumer value of new products and services [5].

In general, it is desirable to use marketing innovation in business processes as the process of organization of marketing activities, communication, value creation, customer relations management.

As mentioned above, the dynamic of marketing innovation applies. These dynamics are three-tiered (bottom, growth and specific), during which innovation may vary with radical and counter-productive processes relative to the production process (Figure 1).

\footnotetext{
6 O'Driscoll, A., Carson, D., \& Gilmore, A. (2000). Developing marketing competence and managing in networks: a strategic perspective. Journal ofStrategic Marketing, 8(2), 183-196

7 Sinkula, J. M. (1994). Market information processing and organizational learning. The Journal of Marketing, 35-45.

8 Weerawardena, J. (2003). The role of marketing capability in innovation-based competitive strategy. Journal of Strategic Marketing, 11(1), 15-35
} 


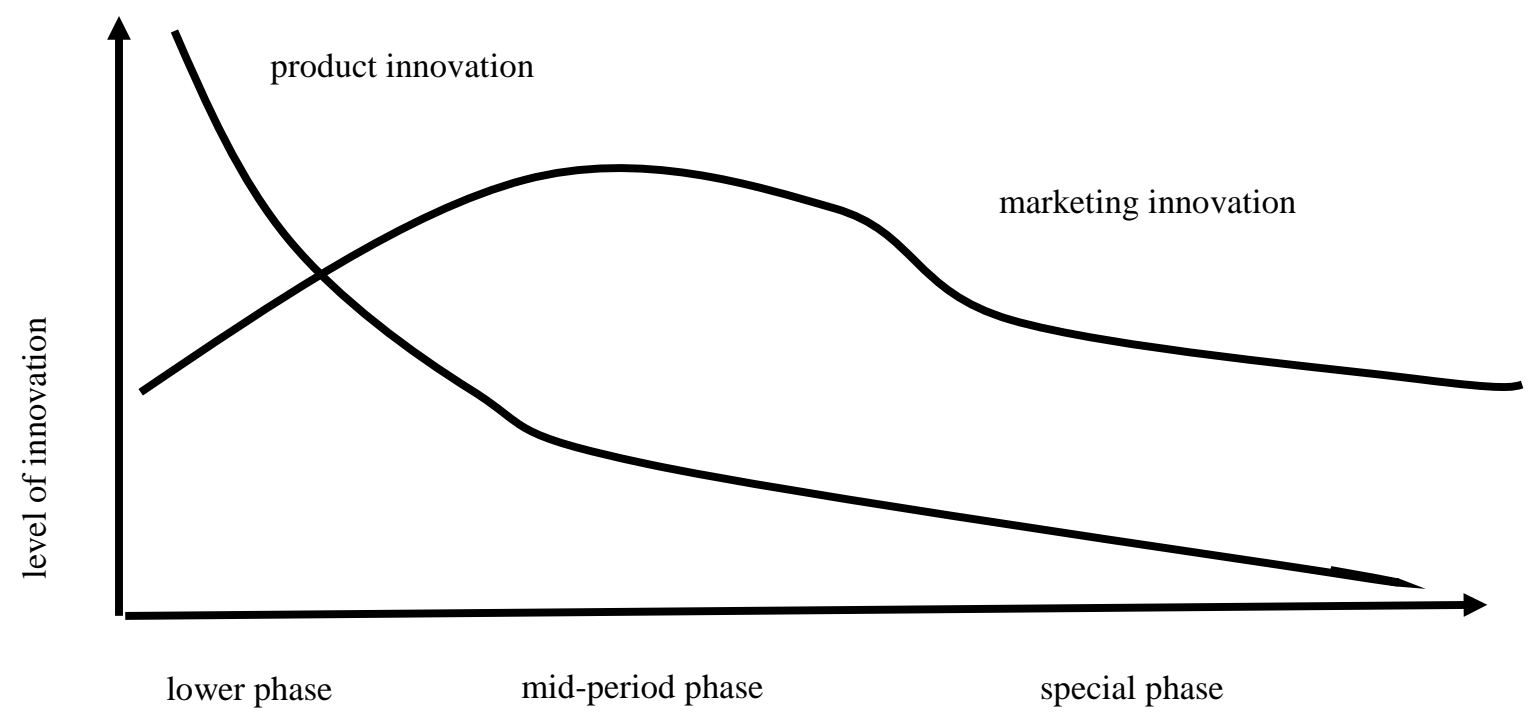

Figure 1. Dynamics of marketing innovation

According to Figure 1, innovation in enterprises is dominated by brand innovation. However, in the later stages of innovative development there is a rapid growth of economic development or marketing innovation in marketing innovations. In most cases, the focus of companies is on product innovation, and the emphasis on marketing innovations is reduced. However, the results of increased competition in the market force marketing innovations to push companies to do so.

\section{Analysis and results}

In total, 4,662 innovations were implemented in the industrial sector of the Republic of Uzbekistan in 2008-2016, of which 4620 were $97 \%$ technological innovations, $1.7 \%$ marketing and $1.3 \%$ innovation (Table 1).

Table 1. Number of technological, marketing, organizational innovations introduced in the Republic of Uzbekistan for 2008-20169

\begin{tabular}{|c|c|c|c|c|}
\hline \multirow[b]{2}{*}{ Years } & \multirow[t]{2}{*}{ Total innovation } & \multicolumn{3}{|c|}{ Including, } \\
\hline & & $\begin{array}{l}\text { Total technological } \\
\text { innovation }\end{array}$ & Marketing & $\begin{array}{c}\text { Total of } \\
\text { organizational } \\
\text { innovation }\end{array}$ \\
\hline 2017 year & 2046 & 1946 & 62 & 38 \\
\hline 2016 year & 981 & 976 & 0 & 5 \\
\hline 2015 year & 889 & 866 & 16 & 7 \\
\hline 2014 year & 882 & 837 & 35 & 10 \\
\hline 2013 year & 693 & 665 & 19 & 9 \\
\hline 2012 year & 288 & 264 & 10 & 14 \\
\hline 2011 year & 307 & 300 & 1 & 6 \\
\hline 2010 year & 248 & 243 & 0 & 5 \\
\hline 2009 year & 231 & 226 & 0 & 5 \\
\hline 2008 year & 243 & 243 & 0 & 0 \\
\hline Total & 6808 & 6566 & 143 & 99 \\
\hline
\end{tabular}

\footnotetext{
9 Ўзбекистон Республикаси статистика қўмитаси маълумоти асосида тайёрланди
} 
The industrial enterprises of the country implemented 143 marketing innovations in 2008-2017, covering the period of 2012-2015. In recent years, the trend of organizational innovation is growing. In total, in the Republic in all spheres in 20172046 innovations were implemented, of which 62 are marketing innovations and 38 are organizational innovations.

\section{Conclusion}

The analysis shows that the economy of Uzbekistan, especially the industry Implementation of effective marketing innovations should be highlighted as key issues on the agenda, with particular emphasis on:

* increasing the number of marketing and consulting firms serving the B2B market, the effective integration of industrial enterprises with them;

* creation of "innovation centers", "innovation incubators" in cooperation with educational institutions in industrial enterprises and creation of separate departments engaged in marketing activities for existing activities;

* the use of innovative marketing technologies developed by foreign companies and used effectively in their work in accordance with national specifics and effective use of benchmarking;

* Development of innovative marketing strategies aimed at effective promotion of the product along with product innovation;

* establishment of special units for marketing innovation development of the Ministry of Innovation Development, established by the Decree of the President of the Republic of Uzbekistan dated November 29, 2017, No. P-5264 "On the establishment of the Ministry of Innovative Development of the Republic of Uzbekistan";

Effective implementation of these tasks will help to further develop the economy of our country, increase the production of competitive products and increase the role of local brands in the global markets.

\section{References}

[1] ัзбекистон Республикаси Президентининг «Ўзбекистон Республикасини янада ривожлантириш бўйича Харакатлар стратегияси тўғрисида»ги Фармони. ПФ-4947-сон, 2017 йил 7 февраль. - Ўзбекистон Республикаси қонун хужжатлари тўплами. 2017 й., 6-сон, 70-модда

[2] Kotabe, M. and Murray, J. Y. 1990 'Linking product and process innovations and modes of international sourcing in global competition: a case of foreign multinational firms', Journal of International Business Studies, Vol.21, No. 3, pp. 383.

[3] Levitt, T. (1960) 'Growth and profits through planned marketing innovation', Journal of Marketing, Vol. April, pp. 1-8

[4] Lin, C. Y.-Y. and Chen, M. Y.-C. (2007) 'Does innovation lead to performance? An empirical study of SMEs in Taiwan', Management Research News, Vol.30, No. 2, pp. 115-132

[5] Magrath, A. J. and Higgins, J. M. (1992) 'Six pathways to marketing innovation, the valueadded analysis: a seventh pathway to marketing innovation’, Planning Review, Vol. 20, pp. 12-19. 